\title{
Development and Validation of a Simple UV Spectrophotometric Method for the Determination of Cefotaxime Sodium in Bulk And Pharmaceutical Formulation
}

\author{
Most. Umme Bushra ${ }^{1 *}$, Nahia Akter ${ }^{2}$, Md. Rajib Hassan ${ }^{2}$,Atikul Islam ${ }^{1,}$ \\ Md. Radwan Hossain ${ }^{1}$, \\ ${ }^{I}$ Department of Pharmacy, Manarat International University, Mirpur, Dhaka, Bangladesh. \\ ${ }^{2}$ Department of Pharmacy, University of Asia pacific,Dhanmondi,Dhaka,Bangladesh
}

\begin{abstract}
The present study was undertaken to develop and validate a simple, accurate, precise, reproducible and cost effective UV-Visible spectrophotometric method for the estimation of cefotaxime sodium in bulk and pharmaceutical formulation. The solvent used throughout the experiment was methanol and water. Absorption maximum $\left(\lambda_{\max }\right)$ of the drug was found to be $260 \mathrm{~nm}$. The quantitative determination of the drug was carried out at $260 \mathrm{~nm}$ and Beer's law was obeyed in the range of $10-30 \mu \mathrm{g} / \mathrm{mL}$. The method was shown linear in the mentioned concentrations having line equation $y=0.025 x+0.0028$ with correlation coefficient $R^{2}$ of 0.9995 . The recovery values for cefotaxime sodium ranged from $99.95 \%-100.21 \%$. The percent relative standard deviation (RSD \%) of interday precision range was $0.099-0.140 \%$ and intraday precision range was $0.098-$ $0.132 \%$. The limit of detection and limit of quantification was $0.079 \mu \mathrm{g} / \mathrm{mL}$ and $0.154 \mu \mathrm{g} / \mathrm{mL}$. The percent relative standard deviation of robustness and ruggedness of the method was $0.142-0.221 \%$. Hence, proposed method was precise, accurate and cost effective. This method could be applicable for quantitative determination of the bulk drug as well as dosage formulation.
\end{abstract}

KEYWORDS: UV-Vis Spectrophotometer, Method Validation, Recovery studies.

\section{INTRODUCTION}

Cefotaxime sodium is a broad spectrum third generation cephalosporin, which is a penicillinaseresistant antibiotic ${ }^{1}$. Its spectrum of activity includes most strains of bacterial pathogens responsible for septicaemia, respiratory tract infections, urinary tract infections, soft tissue infections, bone and joint infections, obstetric and gynaecological infections and other various types of infection $\mathrm{s}^{2-3}$. Literature survey revealed that few analytical methods are available for the individual estimation of cefotaxime sodium by HPTLC ${ }^{4-5}$, by HPLC $^{6-9}$ and by UV spectrophotometric method ${ }^{10-13}$. But single estimation of this drug with the mixer of methanol and water as solvent has not been reported in bulk and in pharmaceutical formulation.

Thus, the aim of the present work was to develop and validate a simple, reproducible and economic analytical method to estimate cefotaxime sodium in routine analysis.

\section{MATERIALS AND METHOD}

Pure Standard of cefotaxime sodium powder was received as a kind gift from Renata Pharmaceuticals Ltd., Bangladesh which was used as reference standard. The commercially available three brands of parenteral preparation containing cefotaxime sodium Cefotax $(250 \mathrm{mg} / \mathrm{vial})$, Taxim $(500 \mathrm{mg} / \mathrm{vial})$ and Maxcef $(1 \mathrm{gm} / \mathrm{vial})$ were purchased from the local market in Dhaka.Apparatus: A Shimadzu UV-Visible spectrophotometer UV1800 was used.

\subsection{Method Development}

2.1.1. Determination of wavelength of maximum absorption: The standard stock solution of $100 \mu \mathrm{g} / \mathrm{mL}$ of cefotaxime sodium was prepared by weighing $100 \mathrm{mg}$ of the drug, taken in $100 \mathrm{~mL}$ volumetric flask and diluted with methanol. By appropriate dilution of standard stock solutions with water, different solutions containing different concentration $(10,15,20,25 \& 30 \mu \mathrm{g} / \mathrm{mL})$ of cefotaxime sodium were scanned in the range of 200-800 $\mathrm{nm}$ to determine the wavelength of maximum absorbance. Cefotaxime sodium has shown maximum absorption at $260 \mathrm{~nm}$.

2.2. Method validation: The proposed method was validated for different parameters like linearity, precision, accuracy, specificity, robustness, LOD, LOQ and assay. 
2.2.1. Linearity Study: The linearity was determined by plotting concentration against corresponding absorbance. Standard stock solutions, $100 \mu \mathrm{g} / \mathrm{mL}$ were further diluted with water to obtain $10 \mu \mathrm{g} / \mathrm{mL}-30 \mu \mathrm{g} / \mathrm{mL}$ solutions. The calibration curves were constructed by plotting absorbance versus concentration and the regression equations were calculated.

2.2.2. Intra-day precision study: Aliquots $(1.0,1.5$ and $2 \mathrm{~mL})$ of the $100 \mu \mathrm{g} / \mathrm{mL}$ cefotaxime sodium stock solution were taken in three volumetric flask and respectively diluted with water to obtain three concentrations of 10,15 and $20 \mu \mathrm{g} / \mathrm{ml}$, respectively. Triplicate absorbance measurements of each were made in thrice time i.e. zero hour, fourth hour and eighth hour and the percentage RSD was calculated.

2.2.3. Inter-day precision study: The selected concentrations for the intra-day precision study were again analysed for consecutive three days and the percentage RSD was calculated.

2.2.4. Accuracy and Recovery Studies: Accuracy of the method was calculated by recovery studies at three different levels $(80 \%, 100 \%$ and $120 \%)$ by standard addition method to study the accuracy of the method and to check the interference from excipients. The first recovery study was conducted on the excipients mixture (placebo) prepared by adding accurately weighed amounts of cefotaxime sodium to the excipient mixture and calculating the percentage recovery in each case.

2.2.5. Specificity in the presence of excipients: The specificity test was carried out using only excipients. Spectra for placebo granules, blank and sample were measured and compared. The sample solution was kept in the oven $\left(60^{\circ} \mathrm{C}\right)$ and under the UV lamp $(254 \mathrm{~nm})$ for $72 \mathrm{~h}$ in order to verify that none of the degradation products interfered with the quantification of the drug.

2.2.6. Robustness: The robustness of an analytical procedure is the measure of its capacity to remain unaffected by small but deliberate variations in method parameters and provides an indication of its reliability during normal usage. It was determined by carrying out the analysis by two analysts at two different temperatures i.e. at $20^{\circ} \mathrm{C}$ and $30^{\circ} \mathrm{C}$. The absorbance was measured and assay was calculated for six times.

2.2.7. Limit of Detection (LOD) and Limit of Quantitation (LOQ): LOD and LOQ were calculated from the data obtained from the linearity studies. The slope of the linearity plot was determined. For each of the ten replicate determinations of same concentration $(6 \mu \mathrm{g} / \mathrm{mL})$, standard deviation (SD) of the responses was calculated.Limit of detection can be calculated by using the following formula:

$\mathrm{LOD}=\frac{3.3 \sigma}{\mathrm{S}}$

Limit of quantitation can be calculated base on standard deviation of the response and the slope.

$\mathrm{LOQ}=\underline{10 \sigma}$

Where $\sigma=$ Standard deviation of the response; $\mathrm{S}=$ Slope of the calibration curve.

2.2.8. Assay of cefotaxime sodium formulations available in Bangladesh:

To analyze the concentration of cefotaxime sodium in the vial, a portion of powder equivalent to $100 \mathrm{mg}$ of cefotaxime sodium was transferred in $100 \mathrm{ml}$ volumetric flask and was diluted with methanol. This solution was further diluted with water to get final concentration of $10 \mu \mathrm{g} / \mathrm{mL}$ of cefotaxime sodium. The $\%$ assay of the drug was calculated. All determinations were conducted by thrice time.

2.2.9. Statistical analysis: The results were expressed as mean \pm SD. Some results were expressed as \%RSD.

\section{RESULTS AND DISCUSSION}

The method discussed in the present work provides a convenient and accurate way for analysis of cefotaxime sodium. The different concentrations of $10-30 \mu \mathrm{g} / \mathrm{mL}$ were scanned and the wavelength of maximum absorption was found at $260 \mathrm{~nm}$ (Figure 1).

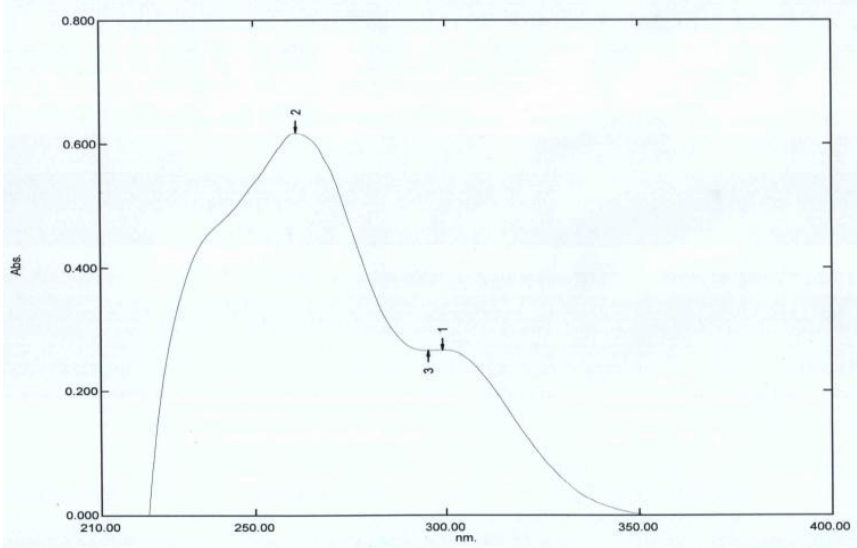

Fig 1: UV spectrum of cefotaxime sodium $\left(\lambda_{\max }\right)$ 
The drug obeyed the Beer's law with the concentration range $10-30 \mu \mathrm{g} / \mathrm{mL}$ having line equation $\mathrm{y}=0.025 \mathrm{x}+$ 0.0028 with correlation coefficient $\mathrm{R}^{2}$ of 0.9995 and represented excellent linear relationship of the newly developed method (Figure 2).The LOD and LOQ of the developed method were determined by injecting progressively low concentrations of the standard solution $(10 \mu \mathrm{g} / \mathrm{mL})$ for 6 times and the values of LOD and LOQ were found to be $0.079 \mu \mathrm{g} / \mathrm{mL}$ and $0.154 \mu \mathrm{g} / \mathrm{mL}$ respectively.

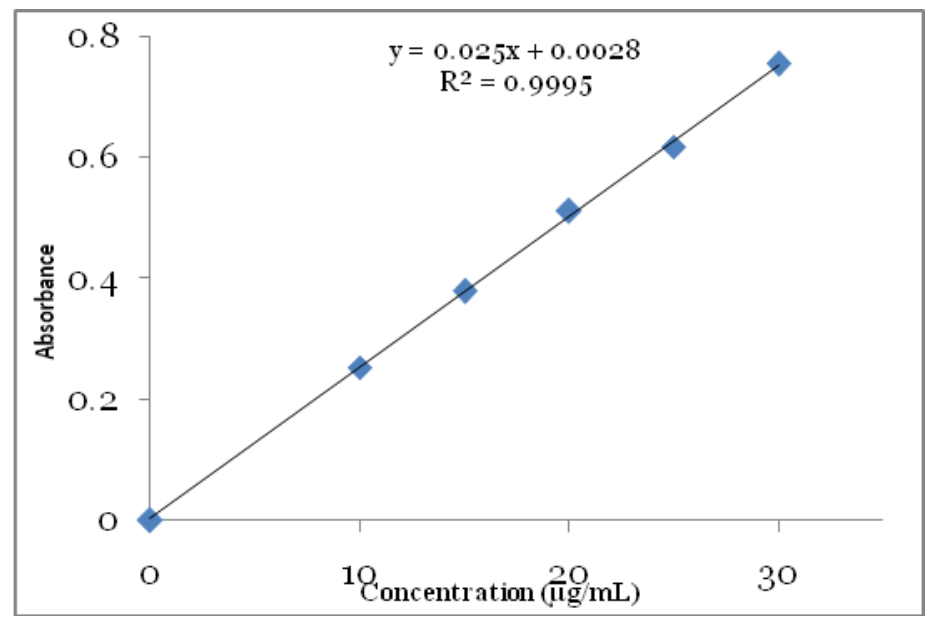

Fig 2. Calibration curve for cefotaxime sodium

The precision of the proposed method was checked by intra-day and inter-day repeatability of responses which confirmed adequate sample stability and method reliability over $24 \mathrm{~h}$ periods where RSD\% amongst responses was found as $<2 \%$ (Table 1 ).

\begin{tabular}{ccccc}
\hline $\begin{array}{c}\text { Concentration } \\
(\boldsymbol{\mu g} / \mathbf{m L})\end{array}$ & $\begin{array}{c}\text { Absorbance measured } \\
(\text { Mean } \pm \text { SD) }\end{array}$ & $\begin{array}{c}\text { \% } \\
\text { RSD }\end{array}$ & $\begin{array}{c}\text { Absorbance measured } \\
(\text { Mean } \pm \text { SD) }\end{array}$ & $\begin{array}{c}\text { \% } \\
\text { RSD }\end{array}$ \\
\hline 10 & $0.2543 \pm 0.0007$ & 0.140 & $0.2324 \pm 0.0009$ & 0.131 \\
15 & $0.3794 \pm 0.0008$ & 0.099 & $0.3847 \pm 0.0007$ & 0.098 \\
20 & $0.5125 \pm 0.001$ & 0.111 & $0.5082 \pm 0.0012$ & 0.132 \\
\hline
\end{tabular}

Table 1: Intra-day and inter-day precision determined for different concentrations of cefotaxime sodium The accuracy was evaluated at three different concentrations which were conducted in successive analysis $(\mathrm{n}=$ 3 ) using the proposed method and the value was expressed as percentage of recovery between the mean concentrations of recovered and injected concentration of the drug. The average recoveries were found to be as $99.95 \%, 100.21 \%$ and $99.98 \%$ for the concentration levels of $80 \%, 100 \%$ and $120 \%$ respectively (Table 2 ).

\begin{tabular}{|c|c|c|c|c|}
\hline \multirow{2}{*}{$\begin{array}{c}\% \\
\text { Recovery }\end{array}$} & \multicolumn{2}{|c|}{$\begin{array}{l}\text { Concentration } \\
(\mu \mathrm{g} / \mathrm{mL})\end{array}$} & \multirow{2}{*}{$\begin{array}{l}\text { \% Avg. } \\
\text { Recovery }\end{array}$} & \multirow{2}{*}{$\begin{array}{c}\% \\
\text { RSD }\end{array}$} \\
\hline & $\begin{array}{c}\text { Amount } \\
\text { added }\end{array}$ & Amount found & & \\
\hline 80 & 10 & $9.99 \pm 0.0065$ & 99.95 & 0.140 \\
\hline 100 & 15 & $15.03 \pm 0.0057$ & 100.21 & 0.260 \\
\hline 120 & 20 & $19.98 \pm 0.0071$ & 99.98 & 0.125 \\
\hline
\end{tabular}

Table2.Determination of accuracy of cefotaxime sodium by UV-Visible spectrophotometer $(n=3)$

The assays were validated by means of the analysis of variance. Cefotaxime sodium content in three brands were determined by this proposed method which were in good agreement with the label claims with RSD value of $0.02 \%, 0.01 \%$ and $0.03 \%$ consecutively (Table 3 ). The \%RSD was found in the range of $0.142-0.221 \%$ for robustness and ruggedness. The specificity of the analytical method was proved by comparing the spectra of placebo and degradation product of sample solution with that of accuracy sample. 


\begin{tabular}{ccccc}
\hline Drug & $\begin{array}{c}\text { Declared } \\
\text { concentration }\end{array}$ & $\begin{array}{c}\text { Found } \\
\text { concentration }\end{array}$ & $\begin{array}{c}\text { Content } \\
(\%)\end{array}$ & $\begin{array}{c}\text { \% } \\
\text { RSD }\end{array}$ \\
\hline Brand A & $10 \mu \mathrm{g} / \mathrm{mL}$ & $9.99 \pm 0.02$ & $99.96 \% \pm 0.02$ & 0.02 \\
Brand B & $10 \mu \mathrm{g} / \mathrm{mL}$ & $9.98 \pm 0.02$ & $99.85 \% \pm 0.01$ & 0.01 \\
Brand C & $10 \mu \mathrm{g} / \mathrm{mL}$ & $10.01 \pm 0.01$ & $100.05 \% \pm 0.01$ & 0.03 \\
\hline
\end{tabular}

Table 3: Assay of cefotaxime sodium in marketed products $(n=3)$

All experimental results were within the range of the acceptability which indicated that the developed method was sensitive enough and accurate for quantitative analysis of cefotaxime sodium. Therefore, the method was applied for quantitative analysis of cefotaxime sodium in bulk and pharmaceutical dosage form.

\section{CONCLUSION}

This UV-spectrophotometric technique was quite simple, accurate, precise, reproducible and sensitive. The UV method has been developed for quantification of cefotaxime sodium in pharmaceutical dosage forms. The validation procedure confirms that this is a workable method for their quantification in the raw material and also in the formulations.

\section{REFERENCES:}

[1] Williams JD, Naber KG, Bryskier A, Hoiby N, Gould IM, Periti P, Giamarellou H, Rouveix B. Int. J. Antimicrob. Agents. 2001; 17:443.

[2] Martindale, The extra pharmacopeia, The pharmaceutical Press,London Edition.29,1989,151.

[3] O.Layne and M.D,Gentry, Cefotaxime and prophylaxic; New approaches with a proven agent.Am.J.Med.,88,1990,S32.

[4] Nanda RK, Bhagwat VV, Potawale SE, Hamane SC, Development and validation of a HPTLC method for simultaneous densitometric analysis of Cefotaxime Sodium and sulbactam sodium as the bulk drugs and in the pharmaceutical dosage form, Journal of Pharmacy Research, 3(7),

[5] Agbaba D., Zivanov-Stakic. Dand Vladimirov. S., HPTLC determination of ceftriaxone, cefixime and cefotaxime in dosage forms., J .Pharm. Biomed Anal., 1998, 18, 893-898. 2010, 1667-1669.

[6] Iqbal MS, Bahari MB, DarwisY, Iqbal MZ, Hayat A, Gantala V. An RP-HPLC-UV Method with SPE for Cefotaxime in All-inOne Total Parenteral Nutritional Admixtures:Application to Stability Studies. Journal of AOAC International. 2013;96 (2):290294.

[7] Victoria F and Emmanouil D., HPLC determination of cefotaxime and cephalexine residues in milk and cephalexine in veterinary formulation., microchimica acta., 2008,160, 471-475.

[8] Jolanta J., Buszman E and Hawranek J., Determination of cefotaxime and desacetylcefotaxime in cerebrospinal fluid by solidphase extraction and high performance liquid chromatography., J. Chromatogr. A., 2002, 976, 249-254.

[9] Barker S. A., Simple liquid chromatographic method for the determination of cefotaxime in human and rat plasma., J. Chromatogr. B., 2003, 783, 297-301.

[10] Patel SA, Patel NM, Patel MM, Spectrophotometric estimation of cefotaxime and ceftriaxone in pharmaceutical dosage forms, Indian Journal of Pharmaceutical Sciences, 68, 2006, 101-103.

[11] Nanda RK, Bhagwat VV, Potawale SE, Vidyasagar NC, Mishra R, Simultaneous Spectrophotometric Estimation of Cefotaxime Sodium and Sulbactam Sodium in Pharmaceutical Dosage Form, International Journal of ChemTech Research, 2(3), 2010, 16121617

[12] Rania AS, Wafaa SH, Magda YE, Abdalla S. New Extractive Spectrophotometric Method for the Determination of Gatifloxacin and Cefotaxime Sodium in Pure and Pharmaceutical Dosage Forms. Oriental Journal of Chemistry.2012;28(2):639-650.

[13] Rania AS, Wafaa SH, Magda YE, Abdalla S. Spectroscopic method for the determination of Cefotaxime Sodium and Cefoperazone sodium in Pure and Pharmaceutical Dosage Forms. American Chemical Science Journal.2013; 3(4):514-525. 